\title{
Hydroxamic acid surface active agents
}

\author{
By M.H.M. Ahmed, A.A. Mahmoud and A.A. El-Sawy
}

\author{
Chemistry Department, Faculty of Science, Benha University, Benha-Egypt
}

\section{RESUMEN}

\section{Tensioactivos derivados del ácido hidroxámico.}

Se han utilizado el p-hidroxideniloctadecanol y et ácido p-hit droxifenibctadecanoico como nuevos precursores para la preparación de tensiosctivos derivados del acido hidroxamico, que incluyen dferentes moles de áxido de propileno. El aicido hidroxemico se proparó por reaccion de los productos propenoxilados con cloroscetalo sódion, seguido de la formación de ésteres me. tilicos, y los productos resultantes se hicieron reeccionar con clorhidrato de hidroxilamina para dar los derivados del acido hidroxámico. Las estructuras de los defivados preparados del aici. do hidroxámico, se confirmaron por técnicas espectroscópicas, estudiandose su actividad superficial cuycs resultados mostraron que dichos compuestos tenian un alto valor. La actividad superficial del sustrato aicohólico tue màyor que la del sustraio ácido

PALABAAS-CLAVE: Acido hidroxamico - Acióo p-hidroxifeniloctadecanoico - Actividad superficial - p-Hidraxifenidoctadecanol.

\section{SUMMARY}

\section{Hydroxamic acid surface active agents.}

p-Hydroxy phenylociadecanol and p-hydroxy phenyloctadecanoic acid were used as new precursors for the preparation of surtace active hydroxamic acid including different moles of propylene covide. The hydrockamic acid was prepared by the reaction of propenoxylated products with sodium chiloroscetate, followed by methyl esterilication and the resultant product reacted with hydroxyl amine hudrochloride to give the hydroxamic acid. The structures of prepared hydroxamic acid were contirmed by spectroscopic study. The surface activity of prepared hydrowamic acid was studied; the results revoalod that the prepared hydroxamic acid has pronounced surface activity the alcohol subetrate shows a surtace activity superior than the acid substrate.

KEY-WORDS: Hydroxamic acid - p-Hydraxy phenyloctadbcano - p-Hydrany phenyioctadocanoic acid - Surtace activity.

\section{INTRODUCTION}

It was stated previously that hydroxamic acids were prepared to investigate their ionization constants [1]. The hydrolysis of substituted phenyl esters and due to the hydroxamate anion is known to be highly nucleophilic toward phenyl esters, some members of long chain aliphatic hydroxamic acids were prepared [2]. Also hydroxamic acids were prepared and studied with regard to chelate with ferric ion for the medical used and as siderophore models [3-5]. The modification of the terminal $\mathrm{OH}$ group of poly(oxyethylene) type of nonionic (alcohol ethoxylate) was reported by introducing functional groups into the end of hydrophilic group of alkoxylated alcohol [6-8]. Also hydroxamic acids with long chain fatty alcohol ethoxylates were prepared, their chelation properties with transition metal and surface active properties were studied. Also these compounds can be used as the hydrolytic enzyme model compounds [9-10]. The synthesis of hydroxamic acid using lipase of Mucor miehei was reported [11]. The propylene oxide, which is next to ethylene oxide of great technical importance, reacts analogously. The adducts of ethylene oxide and propylene oxide are of significance for consumer products [12]. So the aim of the present work is to prepare of hydroxamic acids from two new starting materials (propenoxylated of p-hydroxy phenyloctadecanol and p-hydroxy phenyl octadecanoic acid) and to study their surface active properties. In the present investigation a series of compounds were prepared from both alcohol and acid derivatives with hydroxamic acid at the end of the propylene oxide (cf. Scheme 1).

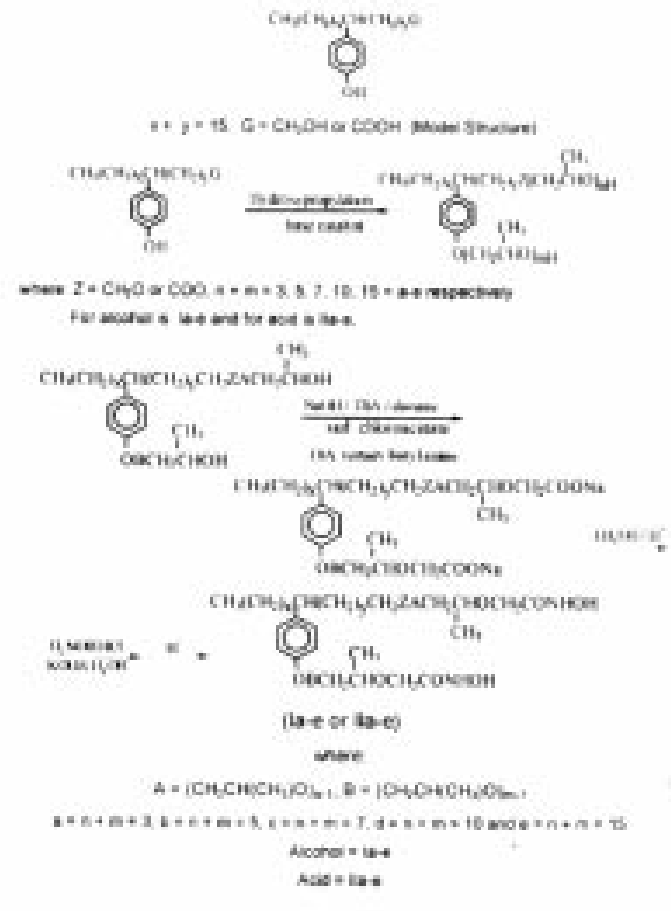

Scherne 1 


\section{EXPERIMENTAL}

\subsection{Preparation of the starting materials}

The starting materials were prepared according to [13]. Thus anhydrous aluminium chloride (1 mole) was added carefully in portion to stirred solution of oleyl alcohol or oleic acid (1 mole) and phenol (6 mole). The temperature rose to $60^{\circ} \mathrm{C}$. The reaction mixture was stirred for $1.5 \mathrm{~h}$., then hydrolysis, distillation under oil vacuum to separate the chloroform and give the crude products, (cf. Table I). The main reaction products are (5) phenyl isomers distributed in alkyl chain from C8 to C13 and small amount of (17) phenyl isomer. In case of $p$-hydroxy phenyloctadecanol greater formation of 5,6 and 7-phenyl isomers are found [13].

Table I

Characterization products of p-hydroxy phenyloctadecanol and octadecanoic acid

\begin{tabular}{|c|c|c|c|c|}
\hline Product & bp & Yiend $\%$ & 'HNMR & $n_{0}{ }^{\prime}$ \\
\hline $\begin{array}{l}\text { p- } \\
\text { hydroxypheny- } \\
\text { octadecanol }\end{array}$ & $209-210$ & 80 & $\begin{array}{c}\delta=0.9(\mathrm{q}, 3 \mathrm{H}, \underline{\mathrm{CH}} 3) ; \delta=2.3(\mathrm{~s}, 3 \mathrm{OH} \\
\left(\mathrm{CH}_{2}\right) 15 ; \delta=3.5 .4(\mathrm{~b}, 1 \mathrm{H}, \text { alc. } \mathrm{OH}) ; \\
\delta=2.9(\mathrm{~m}, 1 \mathrm{H}, \underline{\mathrm{CH}}) ; \delta=3.37(\mathrm{t}, 2 \mathrm{H}, \\
\left.\mathrm{CH}_{2} \mathrm{OH}\right) ; \delta=7.7 .3(\mathrm{~m}, 4 \mathrm{H} \text { arom. }) \text { and } \\
\delta=7.5(\mathrm{~s}, 1 \mathrm{H}, \underline{\mathrm{OH}} \text { phenolic) }\end{array}$ & 1.4923 \\
\hline $\begin{array}{l}\text { p- } \\
\text { hydroxyphenyl } \\
\text { octadecanoic } \\
\text { acid }\end{array}$ & $270-272$ & 72 & $\begin{array}{l}{ }^{1} \mathrm{HNMR} \text { is as in the above, except at } \\
\delta=2.36-2.5\left(2 \mathrm{H}, \mathrm{CH}_{2} \mathrm{COOH}\right) \text { and } \\
\delta=10-12(\mathrm{~b}, 1 \mathrm{H}, \mathrm{COOH}) \text { are different }\end{array}$ & 1.4921 \\
\hline
\end{tabular}

$\mathrm{no}$ : is reflective index at $25^{\circ} \mathrm{C}$

\subsection{Hydroxypropylation of p-hydroxy phenyloctadecanol and p-hydroxy phenyloctadecanoic acid}

Both alcohol and acid with different moles of propylene oxide ( $n=3-15$ mole) were prepared using (0.01 mole) of triethyl amine as base catalyst at $140-160^{\circ} \mathrm{C}$ according to [14].

\subsection{Preparation of methyl ester}

The preparation of methyl ester was done into two steps. First one: (0.1 mole) of propenoxylated compound (derived from alcohol or acid) and (1.0 mole) of powdered sodium hydroxide in $70 \mathrm{ml}$ dioxane were stirred with mechanical stirrer, $(0.6$ mole) of sodium chloroacetate and ( 0.02 mole) of tertiary butyl amine were added to above mentioned suspension solution. The reaction mixture was stirred for $27 \mathrm{~h}$ at $50^{\circ} \mathrm{C}, 300 \mathrm{ml}$ of water was added. The unreacted materials were removed by extraction with petroleum ether $40-60$. The aqueous phase was acidified with hydrochloric acid and extracted several times with ether, dried over anhydrous $\mathrm{Na}_{2} \mathrm{SO}_{4}$, the ether distilled off (normal distillation) to give crude products as viscous olly. The reaction products were followed by TLC in all cases.

Second one: The crude products obtained from the first step was dissolved in excess of methanol and $4 \mathrm{ml}$ conc. $\mathrm{H}_{2} \mathrm{SO}_{4}$ was added, the reaction mixture was stirred at desired reflux temperature for $18 \mathrm{~h}$. After cooling and neutralized with $\mathrm{Na}_{2} \mathrm{CO}_{3}$, the reaction mixture was filtered. The evaporation of solvent gave crude products of methyl ester (cf. Table II). All boiling point higher than $240^{\circ} \mathrm{C}$ at room temperature.

\subsection{Preparation of hydroxamic acid [9]}

\section{General procedure}

(0.02 mole) of methyl ester of propenoxylated (alcohol or acid) in $30 \mathrm{ml}$ methanol was dropped into a mixture of potassium hydroxide $(0.059$ mole) and

Table II

Reaction conditions of the methyl ester products

\begin{tabular}{cccc}
\hline Starting malerial & PO. Unite & Aeaction temp. ${ }^{\circ} \mathrm{C}$ & Yieid $\%$ \\
\hline Alcohol & 3 & & 54 \\
propenoxylated & 5 & & 80 \\
& 7 & $50-70$ & 75 \\
& 10 & & 70 \\
Acid & 15 & & 70 \\
\hline propenoxylated & 3 & & 45 \\
& 5 & & 70 \\
& 7 & $60-80$ & 65 \\
& 10 & & 60 \\
& 15 & & 53 \\
\hline
\end{tabular}


Table III

Characterization of hydroxamic acid

\begin{tabular}{cccc}
\hline Compound & PO unite & Yield $\%$ & Mp ${ }^{2} \mathrm{C}$ \\
\hline la & 3 & 70 & Olly \\
Ib & 5 & 75 & $35-37$ \\
Ic & 7 & 80 & $40-42$ \\
Id & 10 & 80 & $45-46$ \\
le & 15 & 83 & $50-52$ \\
\hline Ila & 3 & 60 & Olly \\
IIb & 5 & 73 & $32-33$ \\
Ilc & 7 & 78 & $38-39$ \\
Ild & 10 & 81 & $48-50$ \\
Ile & 15 & 82 & $55-56$ \\
\hline
\end{tabular}

hydroxyl amine hydrochloride $(0.073$ mole $)$ in $60 \mathrm{ml}$ methanol over 15 min period at approximately $0^{\circ} \mathrm{C}$. The reaction mixture was stirred at room temperature for $18 \mathrm{~h}$ neutralized by $\mathrm{HCl}(\mathrm{pH}=5)$, the insoluble solid was separated by filtration. Evaporation of the solvent from the filtrate gave crude products, the characterization products were given in Table III. The structures of the prepared hydroxamic acid were confirmed by spectroscopic tools (see discussion part).

\section{${ }^{\top}$ HNMR analysis}

Nuclear magnetic resonance spectra were recorded on a Varian EM-390 spectrometer operating at $90 \mathrm{MHz}$. Deutero-chloroform was used as solvent and tetramethyl silane as internal standard. Chemical shifts are reported as (ppm) relative to tetramethyl silane.

\subsection{Determination of the performance properties}

All these properties were completed under neutral conditions, in aqueous phase, using oily and solid prepared samples.

The surface and interfacial tensions

Were measured at $1.0 \mathrm{wt} \%$ aqueous solution at room temperature $\left(25^{\circ} \mathrm{C}\right)$, by using a Du-Nouy tensiometer (Kruss, type 8451) [15].

Cloud Point

Was determined by gradually heating $1.0 \mathrm{wt} \%$ solution in controlled temperature bath and recording the time at which the clear, or nearly clear solutions become definitely turbid. The reproducibility of this temperature was checked by cooling the solutions until they become clear again [16].

\section{Foaming height}

Was measured according to [17]. In this procedure a $25 \mathrm{ml}$ solution $(1.0 \mathrm{wt} \%$ ) was shaken vigorously for 10 seconds in a $100 \mathrm{ml}$ glass stoppered, graduated cylinder, at $25^{\circ} \mathrm{C}$. The solution was allowed to stand for 30 seconds, and the foam height was measured.

Wetting time

Was determined by immersing a sample of cotton fabric in $1.0 \mathrm{wt} \%$ aqueous solution of the surfactants [18].

\section{Emulsion stability}

The emulsion was prepared from $10 \mathrm{ml}$ of a 20 mmol aqueous solution of surfactant and $5 \mathrm{ml}$ of toluene at $40^{\circ} \mathrm{C}$. The emulsifying property was determined by the time it took for an aqueous volume separating from the emulsion layer to reach $9 \mathrm{ml}$ counting from the moment of the cession shaking [19].

\subsection{Biodegradability}

The percentage was determined according to Eter et al. [20].

\section{RESULTS AND DISCUSSION}

\subsection{Synthesis}

The starting materials used in this investigation are p- hydroxyphenyloctadecanol and phydroxyphenyloctadecanoic acid, which were prepared by Friedel-Kratt alkylation of oleyl alcohol or oleic acid to phenol $[13,21]$. Their structures were confirmed by measuring their reflective index [21], IR [22] and 'HNMR (cf. Table I). The preparation of such materials was interesting to produce a model which has two anchor groups with double function surface active agents.

The structure of surface active agent requires a hydrophilic part, this is accomplished by condensation of alkylene oxide at active terminal groups. The addition of propylene oxide in the presence of base catalyst (triethyl amine) at $140-160^{\circ} \mathrm{C}$ gave homologues mixture of propenoxylated products. The average degree of hydroxypropylation was determined by following the increasing in the weight during the hydroxypropylation process and confirmed by a method similar to that described in [23].

The main 'HNMR characteristic band for the prepared propenoxylated compound is $8=3.2 \cdot 4.1$ (m. $\mathrm{CH}_{2} \mathrm{CH}\left(\mathrm{CH}_{3}\right)-\mathrm{O}$ )- propylene glycol unite.

The preparation of methyl ester of propenoxylated compounds is successfully completed in the two pots reaction. The first pot is the reaction of propenoxylated compounds with sodium chloroacetate in the presence of $\mathrm{NaOH}$ and a base catalyst (tertiary butyl amine). followed by second pot reaction in which the products were reacted with methanol in the presence of conc. $\mathrm{H}_{2} \mathrm{SO}_{4}$ (ct. Table II). All the produced methyl ester gave the characteristic IR band of $v_{\mathrm{c}-\infty}$ of ester at $1735-1730 \mathrm{~cm}^{-1}$ and $v_{c o c}$ (str.) at $1220-1230 \mathrm{~cm}^{-1}$. 
The preparation of hydroxamic acid was interesting with a good yields, (cf. Table III). The characteristic 'HNMR bands of hydroxamic acid appeared for the prepared samples at $\delta=4.1-4.2$ (s, $2 \mathrm{H}, \mathrm{O}-\mathrm{CH}_{2}-\mathrm{CO}$ ) and $\delta=9-11$ (br, $2 \mathrm{H}, \mathrm{NHOH}$ ). Also IR bands at $v_{C-O}$ at $1640 \mathrm{~cm}^{-1}, V_{\text {HOH }}$ at $3300-2800$, $1550-900,1440-1360 \mathrm{~cm}^{-1}$.

\subsection{Surface active properties}

The investigation of the surface active properties of the produced hydroxamic acid has been done in the neutral medium, at concentration 1 wt $\%$ and $25^{\circ} \mathrm{C}$. Also they are interesting because these types of the surfactants are not common ones. Therelore the tradtional procedure was used to follow up the properties. The results are represented in Tables IV and $\mathrm{V}$.

Table IV

Surface properties of hydroxamic acid from propenoxylated p-hydroxyphenyloctadecanol

\begin{tabular}{|c|c|c|c|c|c|c|c|}
\hline $\begin{array}{l}\text { Hobourk } \\
\text { acd }\end{array}$ & awe & $\begin{array}{c}\text { Sertace } \\
\text { Wrsien } \\
\text { dyrestan } \\
1.04\end{array}$ & $\begin{array}{l}\text { rerlacal } \\
\text { wrsion } \\
\text { dyresten } \\
1.05\end{array}$ & $\begin{array}{l}\text { chowd } \\
\text { point } \\
\text { c } \\
1.05\end{array}$ & $\begin{array}{l}\text { Fuan } \\
\text { height } \\
\text { inery } \\
1.05\end{array}$ & $\begin{array}{l}\text { Weting } \\
\text { tine } \\
\text { secene } \\
1.05\end{array}$ & $\begin{array}{c}\text { Envinion } \\
\text { min }\end{array}$ \\
\hline la & 3 & 31.0 & 8.0 & 70 & 150 & 58 & 125 \\
\hline it & 5 & 32.0 & 8.5 & 85 & 130 & 55 & 116 \\
\hline IC & 7 & 33.0 & B. 9 & 90 & 120 & 52 & 109 \\
\hline Id & 10 & 34.5 & 9.2 & $>100$ & 100 & 48 & 103 \\
\hline le & 15 & 35.5 & 9.5 & $>100$ & 90 & 43 & 95 \\
\hline
\end{tabular}

Error was:

Surtace and intertacial tensions $= \pm 0,1$ dynes icm.

Cloud point

Foam height

Wetting time

$= \pm 19 \mathrm{C}$

Emulsion

$= \pm 2 \mathrm{~mm}$

$= \pm 1 \mathrm{sec}$.

$= \pm 1 \mathrm{~min}$.

Table V

Surface properties of hydroxamic acid from propenoxylated p-hydroxyphenyloctadecanol

\begin{tabular}{|c|c|c|c|c|c|c|c|}
\hline $\begin{array}{l}\text { Menoule } \\
\text { asid }\end{array}$ & anter & $\begin{array}{c}\text { Sertaca } \\
\text { Wraion } \\
\text { mWn } \\
1.05\end{array}$ & $\begin{array}{l}\text { inerlacial } \\
\text { Wraion } \\
\text { riwn } \\
1.0 \%\end{array}$ & $\begin{array}{l}\text { Faan } \\
\text { hecph } \\
\text { owery } \\
1.05\end{array}$ & $\begin{array}{l}\text { Cikud } \\
\text { point } \\
\text { C } \\
1.0 \mathrm{~s}\end{array}$ & $\begin{array}{l}\text { Wuting } \\
\text { time } \\
\text { vicsne } \\
1.05\end{array}$ & $\begin{array}{c}\text { Envinion } \\
\text { mit }\end{array}$ \\
\hline Ha & 3 & 33.5 & 9.0 & 170 & 67 & 62 & 94 \\
\hline ib & 5 & 34.5 & 9.5 & 165 & 75 & 60 & 90 \\
\hline IIC & 7 & 35.0 & 9.8 & 158 & 76 & 56 & BS \\
\hline IId & 10 & 36.0 & 10.2 & 143 & 80 & 53 & 76 \\
\hline lle & 15 & 37.0 & 11.0 & 135 & $>100$ & 49 & 72 \\
\hline
\end{tabular}

Error was:

Surface and interfacial tensions $= \pm 0.1$ dynes $/ \mathrm{cm}$.

Cloud point

Foam height

Wetting time

$= \pm 10 \mathrm{C}$

$= \pm 2 \mathrm{~mm}$.

$= \pm 1 \mathrm{sec}$.

Emusion

\section{The surface tension and interfacial tension}

The surface tension and interfacial tension data of the prepared compounds are given in Tables IV and $\mathrm{V}$. The surface tension increases with the increase in the molecular weight of hydrophobic moiety [24], On the other hand, the propenoxylated alcohol derivative shows a higher surface activity than that produced from the corresponding acid [21]. The surface activity is improved by introducing hydroxamic acid groups in the molecules. Moreover, the hydroxamic acid produced from alcohol propenoxylated substrate under the same conditions shows a good surface activity in a comparison with that produced from acid (cf. Fig. 1).

It is interesting to find a good relationship between surface tension and propylene oxide units in the study range of the prepared compounds, in which hydroxamic acid group has not any effect on the relationship but it depends on the propylene

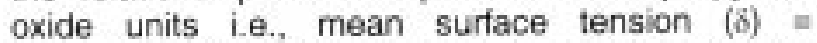
intersection (I) + slope (S) $x$ mean propylene oxide units (6.2), eq. (1) (ct. Table VI).

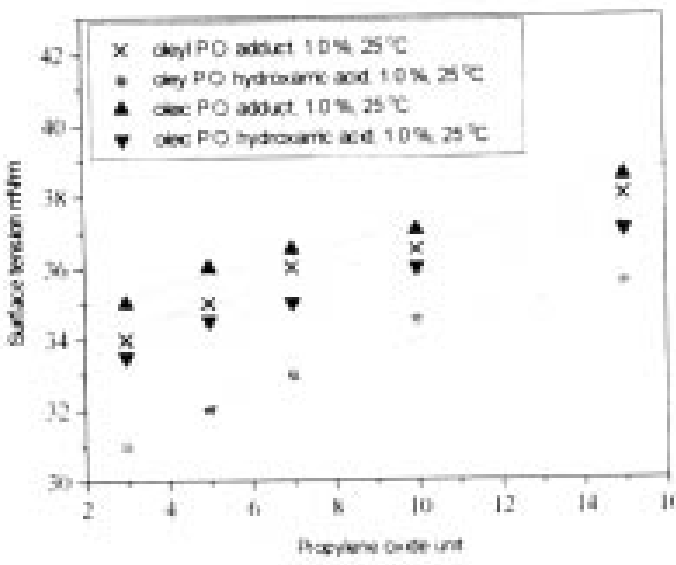

Figure 1

Relationship between the surface vension and propylene oxide unit for propenoxylated and hydroxamic acid (conc. $1.0 \% .25^{\circ} \mathrm{C}$ )

Table Vi

Constants of equ. (1) for the prepared compounds

\begin{tabular}{|c|c|c|c|c|}
\hline Substrate & $\sigma^{+}$ & s' & $\mathbf{r}$ & 8 \\
\hline Oleyl propenoxylate & 0.984 & 0.318 & 33.35 & 35.327 \\
\hline $\begin{array}{l}\text { Oleyl propenoxylate } \\
\text { of hydroxamic acid }\end{array}$ & 0.979 & 0.380 & 30.155 & 32.511 \\
\hline Oleic propenoxylate & 0.988 & 0.272 & 34.41 & 36.203 \\
\hline $\begin{array}{l}\text { Oleic propenoxylate } \\
\text { of hydroxamic acid }\end{array}$ & 0.986 & 0.281 & 32.927 & 34.725 \\
\hline
\end{tabular}

S= slope, I = intersection, $\sigma=$ correlation coefficient, and $\delta=$ mean surtace tension. 


\section{Cloud point}

Generally, the cloud point increases with increasing the number of propenoxy group per hydrophobic molecule [25]. The prepared hydroxamic acid derived from both alcohol and acid substrates show pronounced cloud point than its propenoxylated [22], the alcohol substrates having cloud point higher than the corresponding acid substrate. (cf. Table IV and V).

\section{Foam height}

It was also investigated for the prepared compounds and the results are given in Tables IV and $\mathrm{V}$. It can be seen that the foam height decreases by increasing the propylene oxide unites in the molecule and it is interesting that the acid substrate has superior foam height.

\section{The wetting time}

For the prepared compounds, it decreased with increasing the moles of propylene oxide in the hydroxamic acid molecules. At all points of the investigation, the alcohol substrate shows a better wetting time than the acid. Also a good correlation was lound between the wetting time and number of propylene oxide unites ( $\mathrm{cf}$. Fig. 2).

\section{Emulsion stability}

The produced compounds show pronounced emulsion stability, but the alcohol has emulsion time superior than acid (cf. Fig. 3). Moreover, the emulsion time is in a good correlation with number of propylene oxide unites for both cases.

\section{Biodegradability properties}

The trend of degradation in rive die-away tests was followed by foam and surface tension

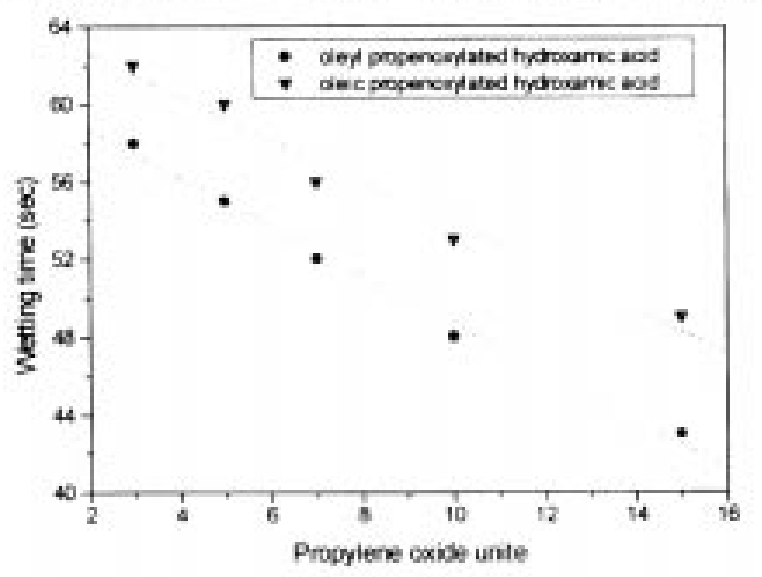

Figure 2

Felationship between the wetting time and propylene oxide unit for propared hydroxamic acid of oleyl and oleic propenoxylated substrate

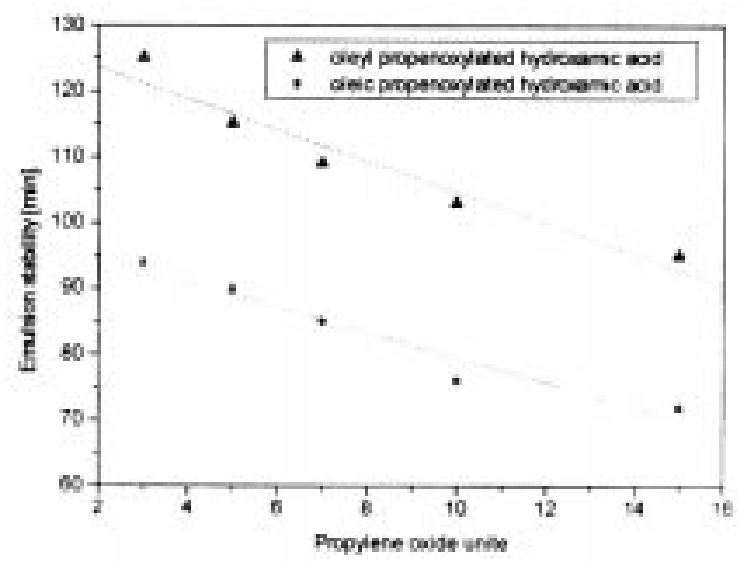

Figure 3

Relationship between the emulsion stability and propylene axide unit for prepared hydroxamic acid of cleyd and deic propenoxylated substrate

measurements. The results are given in Table VII and VIII. The data show that, within the experimental accuracy all the hydroxamic acid of alcohol and acid propenoxylate degraded with approximately the same rate. The rate of degradation of these compounds depends on the size of molecule; bulky molecule diffuses through the cell membrane, and its degradation is more difficult. This means that the hydroxamic acid with lower moles of propylene oxide are more degradable than that which contains higher moles of propylene oxide as appear from (ct. Tables VII and VIII)

Table VII

Biodegradability percentage of alcohol propenoxylated hydroxamic acid

\begin{tabular}{|c|c|c|c|c|c|c|c|}
\hline$n+m$ & $t^{x}$ day & $2^{r e} \mathrm{day}$ & $3^{x d} d a y$ & $4^{n}$ day & $5^{\text {h }}$ day & $6^{\text {th }} d a y$ & $7^{\text {th }} \mathrm{day}$ \\
\hline 3 & 56 & 67 & 75 & 80 & 86 & 90 & 96 \\
\hline 5 & 52 & 60 & 71 & 77 & 83 & 86 & 91 \\
\hline 7 & 46 & 57 & 69 & 75 & 80 & 83 & 86 \\
\hline 10 & 43 & 54 & 57 & 65 & 71 & 75 & 79 \\
\hline 15 & 34 & 41 & 50 & 59 & 64 & 66 & 71 \\
\hline \multicolumn{8}{|c|}{$\begin{array}{l}\text { Table VIII } \\
\text { Biodegradability percentage of acid } \\
\text { propenoxylated hydroxamic acid }\end{array}$} \\
\hline$n+m$ & $1^{\text {al }} d a y$ & $2^{\text {rd }}$ day & $3^{r t} d x y$ & $4^{\text {th }} \mathrm{d} a y$ & $5^{\text {th }} \mathrm{day}$ & $6^{\mathrm{th}} \mathrm{d} z y$ & $7^{\text {th }}$ day \\
\hline 3 & 51 & 63 & 70 & 78 & 82 & 86 & 92 \\
\hline 5 & 50 & 56 & 67 & 72 & 76 & 80 & 85 \\
\hline 7 & 45 & 51 & 60 & 65 & 70 & 76 & 80 \\
\hline 10 & 44 & 50 & 52 & 60 & 66 & 71 & 75 \\
\hline 15 & 38 & 43 & 46 & 54 & 62 & 64 & 69 \\
\hline
\end{tabular}




\section{BIBLIOGRAPHY}

1. Warren, M.W. and Brandt. W.W. (1955). An investigation of some hydroxamic acids. J. Am. Chem. Soc. $77,1058-1059$.

2. Pillersdort, A. and Katzhendler, J. (1979). Dipolar micelles. 8. Hidrolysis of substituted pheny esters in a hydroxamic acid surfactants. J. Org. Chem. 44, 549-554.

3. Richard, K.O. and Ramasamy. K. (1985). Synthesis of retrohydroxamate analogues of the microbial iron-transport agent ferrichrome. J. Org. Chem. 50. 2264-2271.

4. Peter, J.M. and Miller, M.J. (1982). Microbial ifon chelators. J. Am. Chem. Soc. 104, 3096-3101.

5. Bergeron, R.J. (1984). Synthesis and solution structure of microbial siderophores. Chemical Reviews, 84. $587-602$.

6. Schmolka, I.R. (1967). Nonionic surfactants. pp. 300-394. M. Schick (Ed.), Marcel Dekker, Inc., New York. NY.

7. Schönleldt, N. (1969). Surface active ethylene oxide adducts. pp. 632-676. Pergamon Press, Oxford.

8. Shore, S. and Berger, D.R. (1976). Anionic surtactants. Part. I, pp. 135-217. W.M. Linfield (Ed.), Marcel Dekker, Inc. New York NY

9. Masuyama, A., Akiyama, K. and Okahara, M. (1987). Surface active hydroxamic acid. 1. Preparation and properties of long chain alkyl[oligo(oxyethylene)] oxymethylenehydroxamic acids. $\int$. Am. Oif Chem. Soc. 64, 764-768.

10. Masuyama, A., Akiyama, K. and Okahara, M. (1987). Surface active hydroxamic acid. II. Comparison of surlace properties of hydroxamic acids with ketones and methyl esters with similar hydrophilic and lipophilic structure. J. Am OW Chem. Soc. 64, 1040-1043.

11. Servat, F., Montet, D., Pina, M., Galzy, P. Arnaud, A., Ledon. H., Marcou, L. and Graille, J. (1990). Synthesis of fatty hydroxamic acids catalyzed by the lipase of Mucor Miehei. J. Am. Ofr Chem. Soc. 67, 646-649.

12. Schmolka, I.R. (1967). Nonionic surfactants. pp. 300-394. M. Schick (Ed.), Marcel Dekker, Inc. New York. NY.
13. Smith, F.D. Stirton, J and Nuñez-Ponzoa, M.V. (1967). Phenylocta-decanol and surface active derivatives. J Am. OI Chem. 44, 413-415.

14. El-Sawy, A.A., Mahmoud, A.A, and Shaker, N.O. (1990). Preparation and surface active properties of oxypropylated diol monoesters of fatty acids. J. Serb. Chem. Soc. 55, 395-400.

15. Findly. A. (1963). Practical physical chemistry. $6^{\text {th }}$ Ed. 1040. Longmans, London.

16. Durham, K. (1961). Surface activity and detergency. Macmilla Co. Lid. London.

17. Garter, G.N., Frank, G.C. and Barbara, J.H. (1988), Biodegradation of nonionic surfactants containing propylene cxide. $\mathcal{L}$. Am. Oir Chem. Soc. 65, 1669-1676.

18. Draves, C.Z and Clarkso, R. (1931). J. Am. Dye Stutf Aeported, 20, 201

19. El-Sawy, A.A., Essawy, S.A., El-Sukkary, M.M. and Eissa, A.M.F. (1992). Surfactants from 2-hydroxy fatty acids. Hungarian Journal of Incustrial Chemistry, 20. 25-28.

20. Eler, E.T., Richard, R.E. and David, A. (1974). Biodegradable surfactants derived from corn starch. $J$. Am. ON Chemists. Soc, 51, 486-494.

21. Ault, W.C. and Abner, E. (1962). Improved yields in the acid calalyzed addition of phenols and phenyl ethers to oleic acid. J. Am. Or Chem. Soc. 39, 132-133.

22. Eissa. A.M.F., El-Sawy, A.A., Mohmoud, A.A. and Moustafa, M.H. (1996). Preparation of nonionic surfactants with and amide oxime terminal group. Egypt. J. Chem. 39, 465.472.

23. Ahmed, M.M.H. Sallay, P., Rusznák, I and Farkas. L (1995). Determination of the average ethoxylation degree. Tenside Surt. Dot, 33, 410-411.

24. EI-Sawy, A.A. (1992). Synthesis and properties of ampholeric surfactants derived from aspartic acid. Hungarian Joumal of Industrial Chemistry, 20, 29-32.

25. Eissa, A.M.F., Mahmoud, A.A. and El-Sawy, A.A. (1994). Preparation and surlace properties of oxypropylated diol monesters of fatty acids with an amide oxime terminal group. Grasas y Aceites, 45 . 306-308. 